\title{
On Some Weevil Taxa of the Subfamily Entiminae (Coleoptera, Curculionidae) Described by V. I. Motschulsky from Japan and New Data on the Morphology of the Tribes Cneorhinini and Tanymecini
}

\author{
V. Yu. Savitsky, \\ a Zoological Museum of Lomonosov Moscow State University, Moscow, 125009 Russia \\ *e-mail: alophus@gmail.com
}

Received March 23, 2021; revised May 1, 2021; accepted May 1, 2021

\begin{abstract}
Lectotypes of Cneorhinus viridimetallicus Motschulsky, 1860, C. cuprescens Motschulsky, 1866, C. nodosus Motschulsky, 1860, and Dermatodes carinulatus Motschulsky, 1866 are designated. A new synonymy Catapionus viridimetallicus (Motschulsky, 1860) (= Cneorhinus cuprescens Motschulsky, 1866, syn. n.) and a new combination Scepticus carinulatus (Motschulsky, 1866), comb. n. are established. New data on the morphology of some genera of the tribes Cneorhinini and Tanymecini are presented. The record of Amystax fasciatus Roelofs, 1873 for Kunashir Island is shown to be based on misidentification of Scepticus carinulatus.
\end{abstract}

Keywords: Cneorhinini, Tanymecini, Catapionus, Dermatoxenus, Dermatodes, Scepticus, Meotiorhynchus, Amystax, synonymy, morphology, Japan, Kunashir Island

DOI: $10.1134 / \mathrm{S} 001387382004059$

This paper continues the series of publications reporting the results of my study of V.I. Motschulsky's collection kept at the Zoological Museum of Lomonosov Moscow State University (ZMMU) (Savitsky, 2018, 2020). Here I designate the lectotypes of Cneorhinus viridimetallicus Motschulsky, 1860, C. cuprescens Motschulsky, 1866, C. nodosus Motschulsky, 1860, and Dermatodes carinulatus Motschulsky, 1866, establish a new synonymy and clarify the taxonomic position of $D$. carinulatus, give new morphological data for some genera of the tribes Cneorhinini and Tanymecini, and also demonstrate that the previous records of Amystax fasciatus Roelofs, 1873 for Kunashir Island were erroneous.

This work was greatly helped by the publication of the major monograph by $\mathrm{K}$. Morimoto and co-authors (Morimoto et al., 2015) on weevils of the subfamily Entiminae in the fauna of Japan.

V.I. Motschulsky received entomological material from Japan twice (Motschulsky, 1860, 1866; Savitsky, 2020).
When labeling the insects from the first batch, he indicated the collection locality as "Japan," whereas in the labels of the insects from the second batch the locality was indicated as "Japonia." Besides, the type specimens from the first batch usually have a small additional label "type," while those from the second batch have no such label. This information should be taken into account when deciding whether a particular specimen belongs to the type series, because some species described from Japan by V.I. Motschulsky in his first paper (Motschulsky, 1860) were also represented in the second batch of material.

\section{MATERIALS AND METHODS}

This work is based on examination of the material kept in the ZMMU collection and kindly provided by my colleagues.

The body length was measured with an eyepiece micrometer, from the anterior margins of the eyes to the tip of the elytra. The type specimens were mounted 
using the previously described technique (Davidian and Savitsky, 2017). The genitalia and terminalia were studied at magnifications up to $\times 400$ and documented from glycerol preparations, using a Micromed-3 microscope equipped with a ToupCam 9.0 MP digital eyepiece camera.

The type localities for the species described from Japan by V.I. Motschulsky were determined based on the historical facts described earlier (Savitsky, 2020).

\section{RESULTS}

\section{Subfamily Entiminae}

Tribe Cneorhinini

Genus Catapionus Schoenherr, 1842

Catapionus viridimetallicus (Motschulsky, 1860)

Cneorhinus viridimetallicus Motschulsky, 1860 : 21.

$=$ Cneorhinus cuprescens Motschulsky, 1866:178, syn. n.

I studied three syntypes of Cneorhinus viridimetallicus Motschulsky, 1860 (ZMMU).

The lectotype designated herein is a male with the following labels (Fig. 1, 6): (1) a tiny yellow square; (2) "type": a small label in V.I. Motschulsky's handwriting on white paper; (3) "Cneorhinus viridimetallicus Motsch Japan" in V.I. Motschulsky's handwriting on yellow paper; (4) "Lectotypus Cneorhinus viridimetallicus Motschulsky, 1860 V. Savitsky des. 2021" in V.Yu. Savitsky's handwriting on red paper; (5) "Zoological Museum of MSU (Moscow, RUSSIA) [in Russian] № ZMMU Col 02577 Zool. Mus. Mosq. Univ. (Mosquae, ROSSIA) ex. coll. V.I. Motschulsky" printed on pink paper.

The lectotype (Fig. 1; Fig. 2) is remounted onto a rectangular cardboard plate, with the abdominal ventrites glued separately in the back left corner. The cleaned genitalia and terminalia are kept in a microvial with glycerol. The specimen is complete, with a hole from the mounting pin in the right elytron. The body is $11.4 \mathrm{~mm}$ long and $5.2 \mathrm{~mm}$ wide.

The two paralectotypes are females with identical sets of labels: (1) a tiny yellow square; (2) "Paralectotypus Cneorhinus viridimetallicus Motschulsky, 1860
V. Savitsky des. 2021" in V.Yu. Savitsky's handwriting on red paper; (3) an inventory label printed on pink paper with the numbers "№ ZMMU Col 02578" and “№ ZMMU Col 02579” respectively. The paralectotype with the number " 02578 " is complete; it is remounted in the same way as the lectotype. Its body is $12.9 \mathrm{~mm}$ long and $6.5 \mathrm{~mm}$ wide (Fig. 3, 5-7, 9, 10). The other paralectotype is pinned; its abdomen is partly damaged, and its internal parts are destroyed by dermestids.

Type locality of Cneorhinus viridimetallicus: Hokkaido Island, environs of Hakodate or Honshu Island, north of Tokyo.

One syntype was studied: Cneorhinus cuprescens Motschulsky, 1866 (ZMMU), a female which is designated here as the lectotype. The specimen has the following labels (Fig. 4, 6): (1) a tiny yellow square; (2) "Cneorchinus [sic!] cuprescens Motsch. Japonia." in V.I. Motschulsky's handwriting on yellow paper; (3) "Lectotypus Cneorhinus cuprescens Motschulsky, 1866 V. Savitsky des. 2021" in V.Yu. Savitsky's handwriting on red paper; (4) "Zoological Museum of MSU (Moscow, RUSSIA) [in Russian] № ZMMU Col 02574 Zool. Mus. Mosq. Univ. (Mosquae, ROSSIA) ex. coll. V.I. Motschulsky" printed on pink paper.

The lectotype (Fig. 3, 1-4, 8; Fig. 4) is remounted onto a rectangular cardboard plate, with the abdominal ventrites glued separately in the back left corner. The cleaned genitalia, terminalia, and proventriculus are kept in a microvial with glycerol. The onychium of the middle right tarsus in the lectotype is missing, the right elytron has a hole from the mounting pin, the genitalia and terminalia are partly damaged (Fig. 3, 2-4), and the internal parts are destroyed by dermestids. The body is $12.2 \mathrm{~mm}$ long and $5.9 \mathrm{~mm}$ wide.

Type locality of Cneorhinus cuprescens: Hokkaido Island, environs of Hakodate.

The lectotype of Cneorhinus cuprescens differs from females of Catapionus viridimetallicus only in the color of scales and belongs to a color form of this variable species, as was justly supposed earlier by K. Morimoto and co-authors (Morimoto et al., 2015). On this basis, I establish the above synonymy.

The data below were obtained by examining the types of Cneorhinus viridimetallicus and C. cuprescens and also the material from Kunashir and Sakhalin islands. 


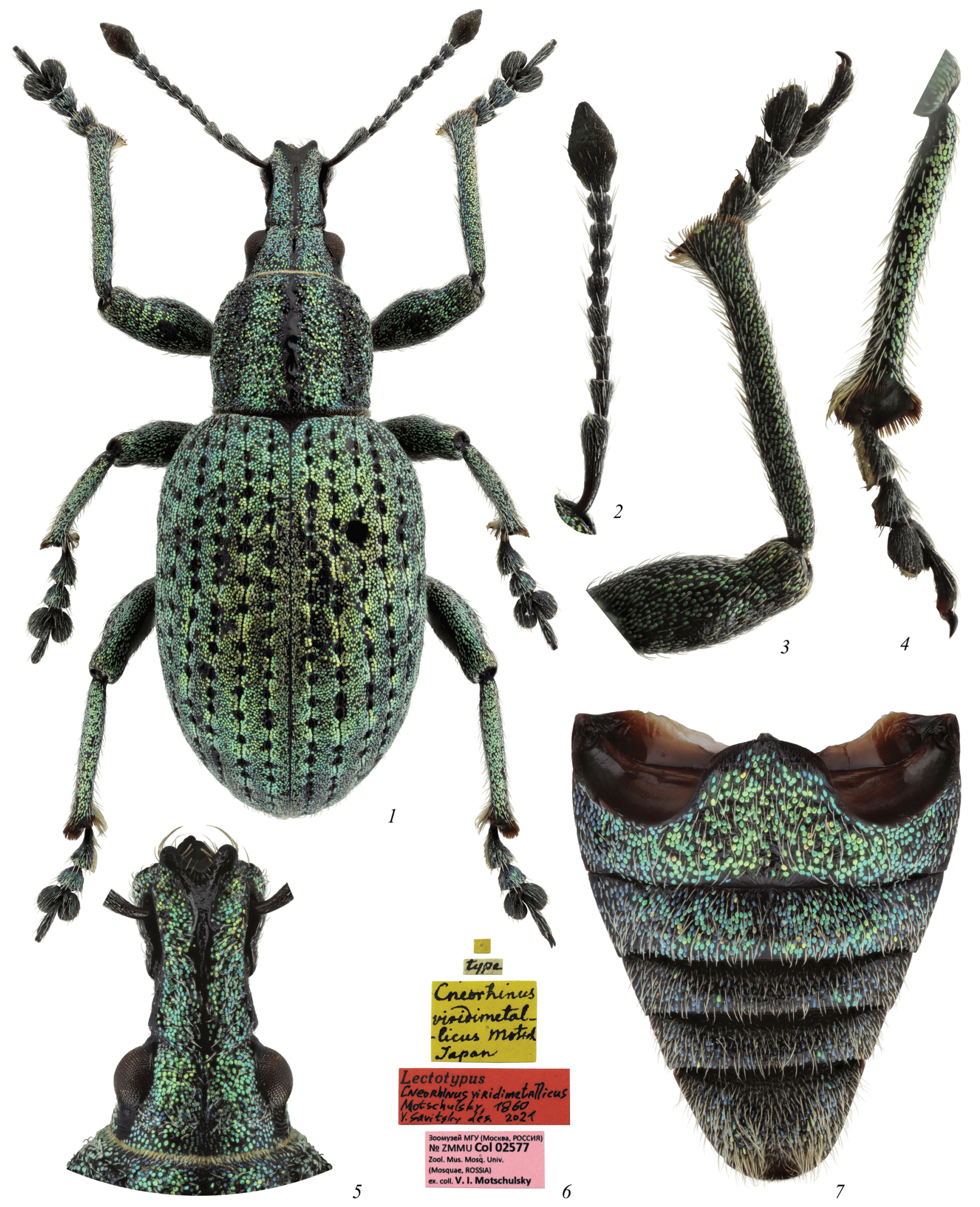

Fig. 1. Cneorhinus viridimetallicus Motschulsky, lectotype: (1) habitus, (2) right antenna, (3) fore right leg, (4) hind right leg, (5) head in dorsal view, (6) labels, (7) venter. 


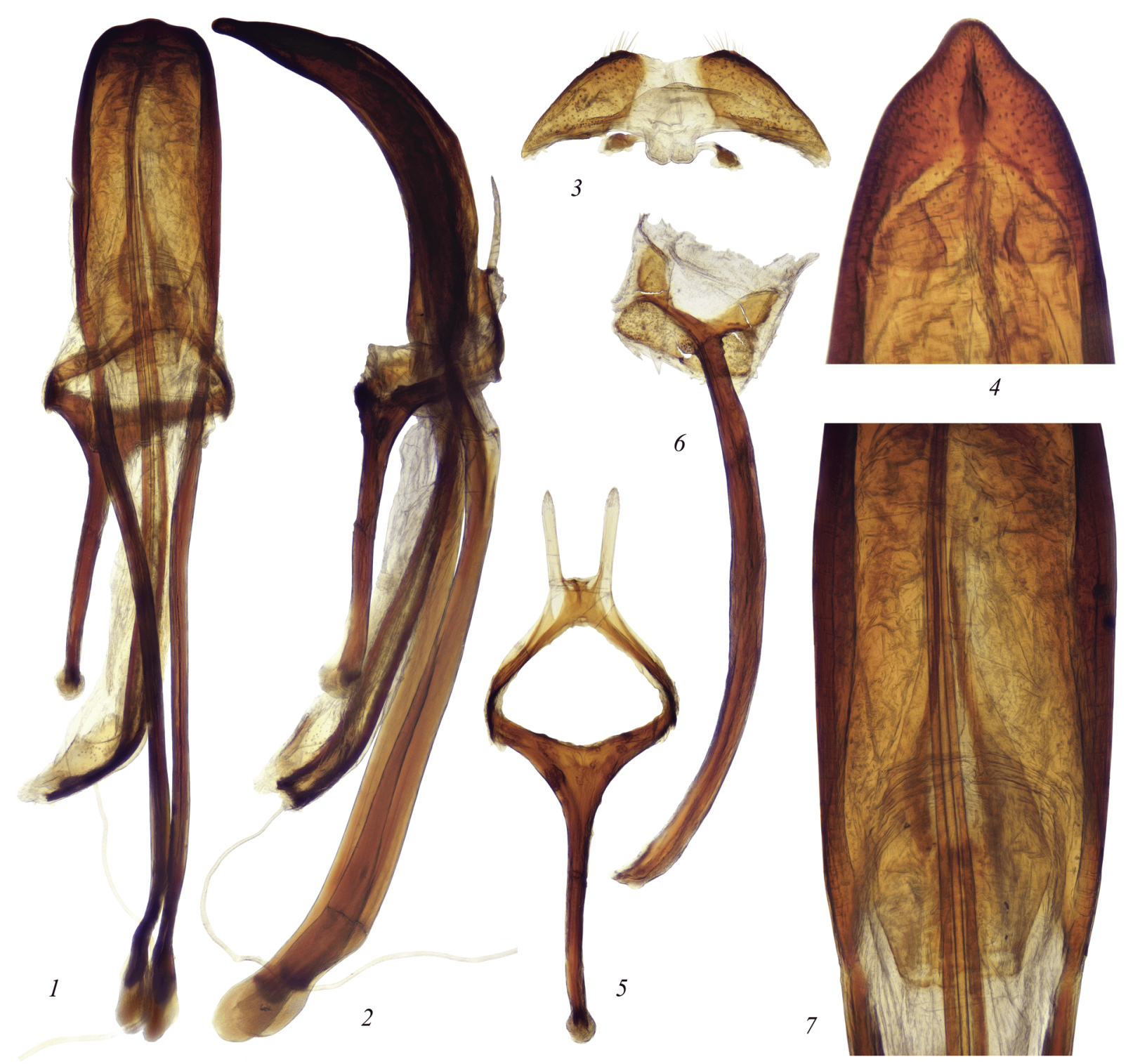

Fig. 2. Cneorhinus viridimetallicus Motschulsky, lectotype: (1) aedeagus in dorsal view, (2) aedeagus in lateral view, (3) sternite VIII in ventral view, (4) apex of aedeagus in ventral view, (5) tegmen in dorsal view, (6) spiculum gastrale, (7) middle part of aedeagus in dorsal view.

They supplement the previously published description of Catapionus viridimetallicus (Morimoto et al., 2015).

Male. Elytra usually merged along suture. Wings strongly reduced, lobe-shaped, 3.3-4.8 times as long as wide, without distinct veins; elytra 1.3-1.9 times as long as wings. Corbels of hind tibiae elongate oval, glabrous or only with several setae and small elongate scales.

Abdomen 1.1-1.2 times as long as wide. Intercoxal protrusion of ventrite I 1.05-1.30 times as wide as coxal cavities. Anal ventrite with preapical depression, its apex dorsally with 2 protrusions. Sternite VIII usually with 2 small sclerites in proximal part.

Tegmen with long manubrium and with parameres positioned wide apart. Apophyses and endophallus much longer than penis tube. Aggonoporium (flagellum in the terminology of Morimoto et al., 2015) composed of paired acicular sclerites extending along entire length of endophallus, connected basally by bridge, and gradually narrowing toward ostium. Ejaculatory duct developed along entire length of endophallus, positioned between 

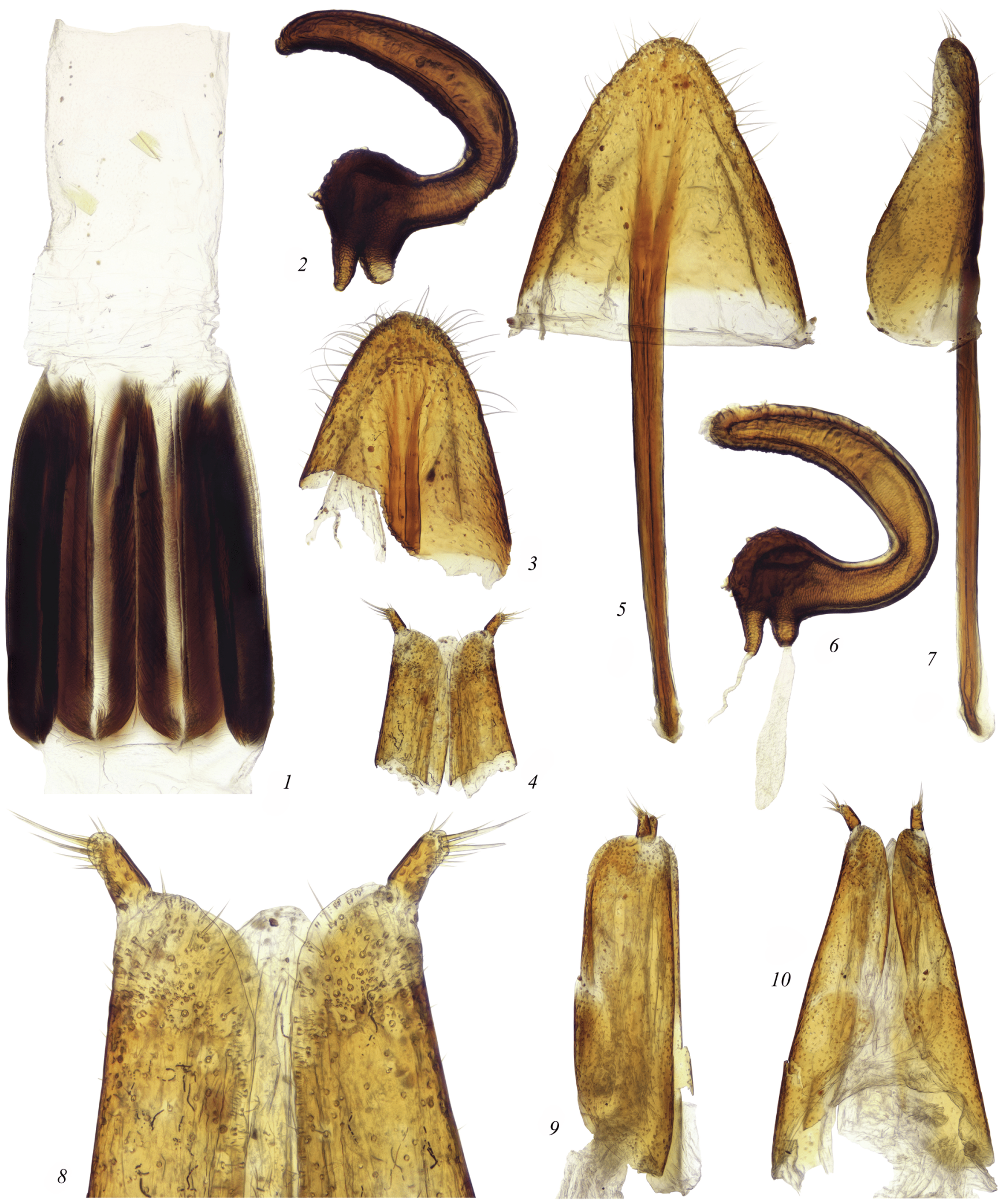

Fig. 3. Crop and proventriculus $(1)$, spermatheca $(2,6)$, spiculum ventrale in ventral $(3,5)$ and lateral view $(7)$, coxites in dorsal $(4,10)$ and lateral view (9), and apex of coxites in dorsal view (8): (1-4,8) Cneorhinus cuprescens Motschulsky, lectotype, (5-7, 9, 10) Cneorhinus viridimetallicus Motschulsky, paralectotype. 
sclerites of aggonoporium; duct walls membranous before endophallus and sclerotized inside it. Ventral wall of endophallus at the level of middle portion of penis tube with U-shaped plate, moderately sclerotized over greater part of its area and with strongly sclerotized inner margins of its lobes ("pair of supporting stripes" in Morimoto et al., 2015).

Crop unarmed. Lobes of proventriculus distally with merged plates.

Female. Anal ventrite with longitudinal preapical depression, its apex dorsally without protrusions.

Lamella of spiculum ventrale weakly transverse, with quite narrowly rounded apical margin and excurved lateral margins. Manubrium 1.25-1.75 times as long as lamella, narrow; caput quite small. Tergites VII and VIII transverse, with widely incurved lateral margins, covered only with simple setae; apical margin of tergite VII weakly emarginate, that of tergite VIII narrowly rounded or blunted.

Coxites rather long, moderately sclerotized, approximately uniformly sculptured along their entire length. Styli apical, elongate, with 6-12 setae in apical half. Vagina longer than coxites, 2-3 times as long as bursa copulatrix; bursa with 2 small, elongate, weakly and nonuniformly sclerotized plates at its joining with spermathecal duct. Cornu of spermatheca falciform, collum and ramus small, collum slightly longer and narrower than ramus. Basal part of cornu, collum, and ramus with reticulate and striate microsculpture. Spermathecal duct not sclerotized, in distal portion strombuliform, gradually thickening.

Distribution. Russia (Sakhalin Island, the Southern Kuril Islands), Japan. The previous records of C. viridimetallicus for East Siberia, Northeast China, and Korea (Morimoto et al., 2015; Alonso-Zarazaga et al., 2017, etc.) remain to be confirmed; all these records probably refer to the closely related species C. fossulatus Motschulsky, 1860.

\section{Morphological Notes on Weevils of the Tribe Cneorhinini}

All the species of the genus Catapionus studied by me (over 20 species, including the type species C. basilicus Boheman, 1842) have glabrous or sparsely pubescent corbels and glabrous articulatory areas of the hind tibiae, and also a characteristic structure of the aggonoporium and ejaculatory duct, described above for C. viridimetallicus. A similar morphology of the aggonoporium is also observed in species of the genera Dermatoxenus Marshall, 1916 and Eustalida Faust, 1891. In my opinion, these genera are the closest to Catapionus but differ well from the latter in the hind tibiae with corbels completely covered with scales. In some species of Dermatoxenus from India, Vietnam, and Indonesia, the greater part of articulatory areas of the hind tibiae is also densely covered with scales (Marshall, 1916; Mahendiran and Ramamurthy, 2012; my data).

In all the species of the genus Dermatodes Schoenherr, 1840 studied by me $(7$ species from the islands of Java, Sumatra, and Borneo), and also in Dermatodina prosvirovi Savitsky, 2021 and D. holynskiorum (Kania et Stojczew, 2001), the corbels and the greater part of articulatory areas of the hind tibiae are densely covered with scales (Kania and Stojczew, 2001; Savitsky, 2021). There are no exact data on the apical pubescence of the hind tibiae in other species of the genera Dermatodina and Antinia Pascoe, 1871. In all the species of the Madagascan genus Stigmatrachelus Schoenherr, 1840 studied by me (over 10 species, including the type species S. cinctus (Olivier, 1807)), the corbels of the hind tibiae are densely covered with scales while their articulatory areas are glabrous. Thus, the pubescence patterns of the corbels and articulatory areas of the hind tibiae may be useful for diagnostics of supraspecific taxa in the tribe Cneorhinini, even though these features are rarely mentioned in descriptions.

It should also be noted that the aggonoporium in species of the genera Dermatodes, Dermatodina, Antinia, and Stigmatrachelus, as well as in most Curculionidae, is much shorter and has a different shape as compared with that in species of the genera Catapionus, Dermatoxenus, and Eustalida (e.g., see Kania and Dąbrowska, 1995; Kania and Stojczew, 2001; Morimoto et al., 2015; Kania and Piwnik, 2017; Savitsky, 2021).

Strongly reduced lobe-like wings without distinct veins, as in Catapionus viridimetallicus, are also typical of all the other Catapionus species studied by me in this respect: C. basilicus, C. ballioni Heyden, 1880, C. fossulatus, and C. mopsus Grebennikov, 2016.

Small paired additional sclerites of sternite VIII that are present in most males of Catapionus viridimetallicus (Fig. 2,3), can also be found in males of C. ballioni, 

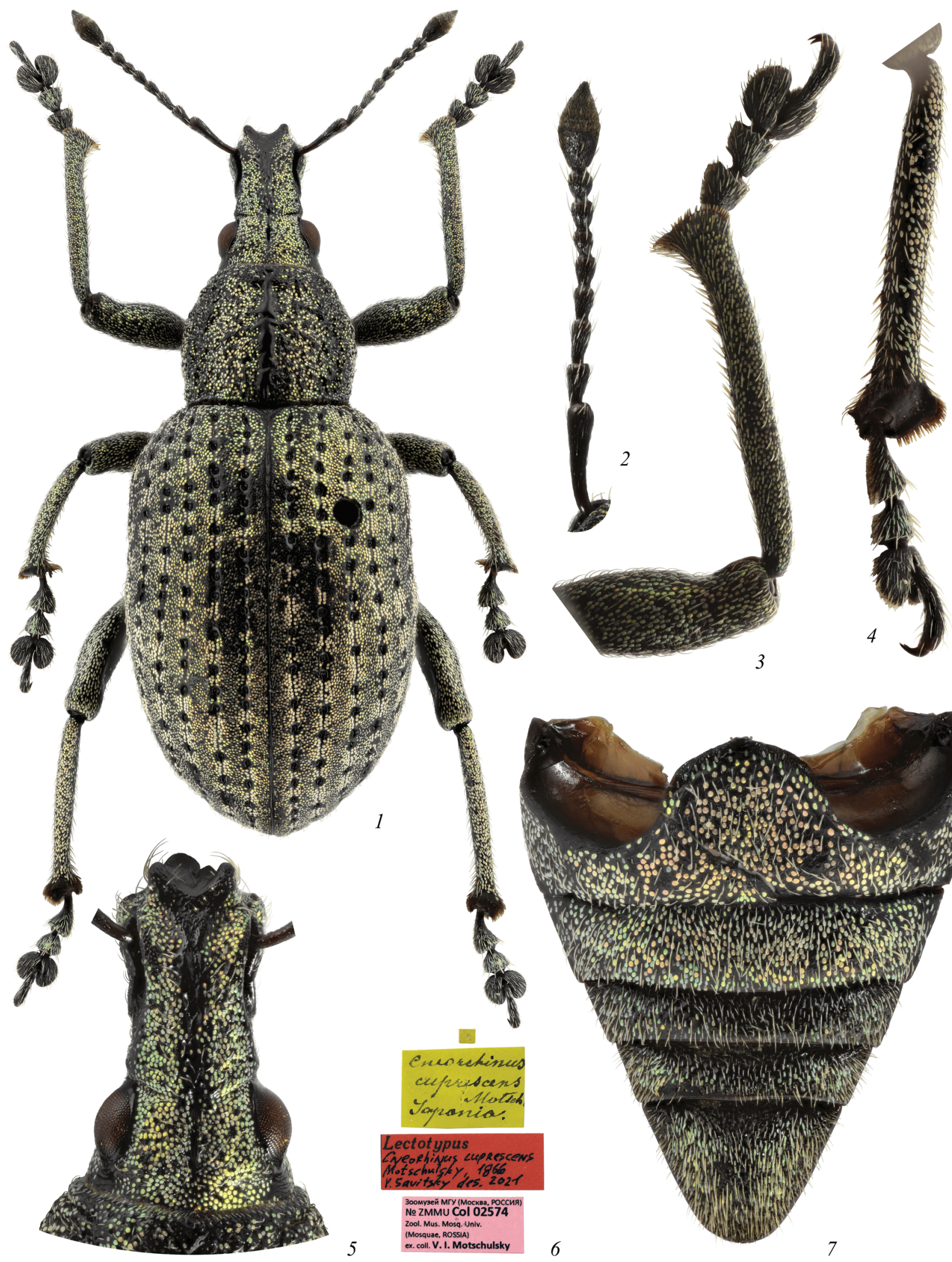

Fig. 4. Cneorhinus cuprescens Motschulsky, lectotype: (1) habitus, (2) left antenna, (3) fore right leg, (4) hind right leg, (5) head in dorsal view, (6) labels, (7) venter. 
C. fossulatus, Dermatodes albarius Faust, 1892, Eustalida sp. from Nepal, and Dermatoxenus sp. from Vietnam. Similar additional sclerites of sternite VIII were earlier described in males of Notaris aethiops (Fabricius, 1792), Brachyderes lusitanicus (Fabricius, 1781), Dermatoxenus indicus Marshall, 1916, some species of Otiorhynchus Germar, 1822, and many species of the subfamily Baridinae (Thompson, 1992; Davidian and Savitsky, 2006; Mahendiran and Ramamurthy, 2012; Yoshihara, 2016). In males of $C$. viridimetallicus and $C$. fossulatus these additional sclerites of sternite VIII vary strongly in the degree of development and may be totally absent in some specimens; therefore, additional research is needed to determine the diagnostic value of this character within the tribe Cneorhinini.

The ejaculatory duct in most Curculionidae ends with the gonopore at its joining with the endophallus. The endophallus walls surrounding the gonopore are usually reinforced with an aggonoporium. During copulation the endophallus is completely everted through the ostium, so that the aggonoporium and gonopore get inserted into the vagina or the bursa copulatrix, and the sperms are transferred through the gonopore into the female reproductive tract.

As described above, in species of the genus Catapionus the aggonoporium and the ejaculatory duct are developed along the entire length of the endophallus. Together they form a single element that lies freely in the endophallus cavity, while the gonopore opens near the ostium of the aedeagus. Correspondingly, it may be supposed that during copulation of Catapionus weevils the endophallus is not everted but folded inside the penis tube, and only the aggonoporium is completely or partially extended through the ostium. This hypothesis can only be confirmed by thorough observations of the mating process in Catapionus weevils. This functional variant may be less injurious to the membranous walls of the endophallus, as compared with the usual mechanism of complete eversion.

Genus Dermatoxenus Marshall, 1916

Dermatoxenus caesicollis (Gyllenhal, 1833)

=Cneorhinus nodosus Motschulsky, $1860: 21$.

One syntype was studied: Cneorhinus nodosus Motschulsky, 1860 (ZMMU), a female which is designated here as the lectotype. The specimen has the following labels (Fig. 5, 6): (1) a tiny yellow square; (2) "type" in V.I. Motschulsky's handwriting on white paper; (3) "Cneorhinus nodosus Motsch Japan" in V.I. Motschulsky's handwriting on yellow paper; (4) "Lectotypus Cneorhinus nodosus Motschulsky, 1860 V. Savitsky des. 2021 " in V.Yu. Savitsky's handwriting on red paper; (5) "Zoological Museum of MSU (Moscow, RUSSIA) [in Russian] № ZMMU Col 02745 Zool. Mus. Mosq. Univ. (Mosquae, ROSSIA) ex coll. V.I. Motschulsky" printed on pink paper.

The lectotype (see Fig. 5; Fig. 6) is remounted onto a rectangular cardboard plate, with the abdominal ventrites glued separately in the back left corner. The metathorax and wings are glued onto a separate rectangular plate of transparent plastic; the genitalia, terminalia, and proventriculus are kept in a microvial with glycerol. The right elytron has a hole from the mounting pin. The body is $11.2 \mathrm{~mm}$ long and $5.2 \mathrm{~mm}$ wide.

Type locality of Cneorhinus nodosus: Hokkaido Island, environs of Hakodate or Honshu Island, north of Tokyo.

V.I. Motschulsky's collection also includes a female of Dermatoxenus caesicollis with the following labels: (1) a tiny yellow square; (2) "Dermatodes nodosus Motsch Japonia" in V.I. Motschulsky's handwriting on yellow paper; (3) an inventory label printed on pink paper with the number “№ ZMMU Col 02746." This specimen is not a syntype of Cneorhinus nodosus because it was received by V.I. Motschulsky with the second batch of material from Japan, when the description of $C$. nodosus had already been published. This is confirmed by the fact that V.I. Motschulsky indicated the collection locality as "Japonia" (see Introduction) and labeled the specimen as Dermatodes, in the same way as in his second paper on the Japanese insects (Motschulsky, 1866).

When describing this species, V.I. Motschulsky supposed that it might belong to a new genus: "Cneorhinus? nodosus Motsch., elongatus, gibbosus... Forsan novum genus." (Motschulsky, 1860). Later he included the species in the genus Dermatodes Schoenherr, 1840 (Motschulsky, 1866, 1870). Still later, Tournier (1876) and Sharp (1896) placed Cneorhinus nodosus in the genus Catapionus, and Marshall (1916) transferred it to the genus Dermatoxenus Marshall, 1916. The subsequent authors (Emden and Emden, 1939; Morimoto et al., 2015; Alonso-Zarazaga et al., 2017, etc.) consid- 


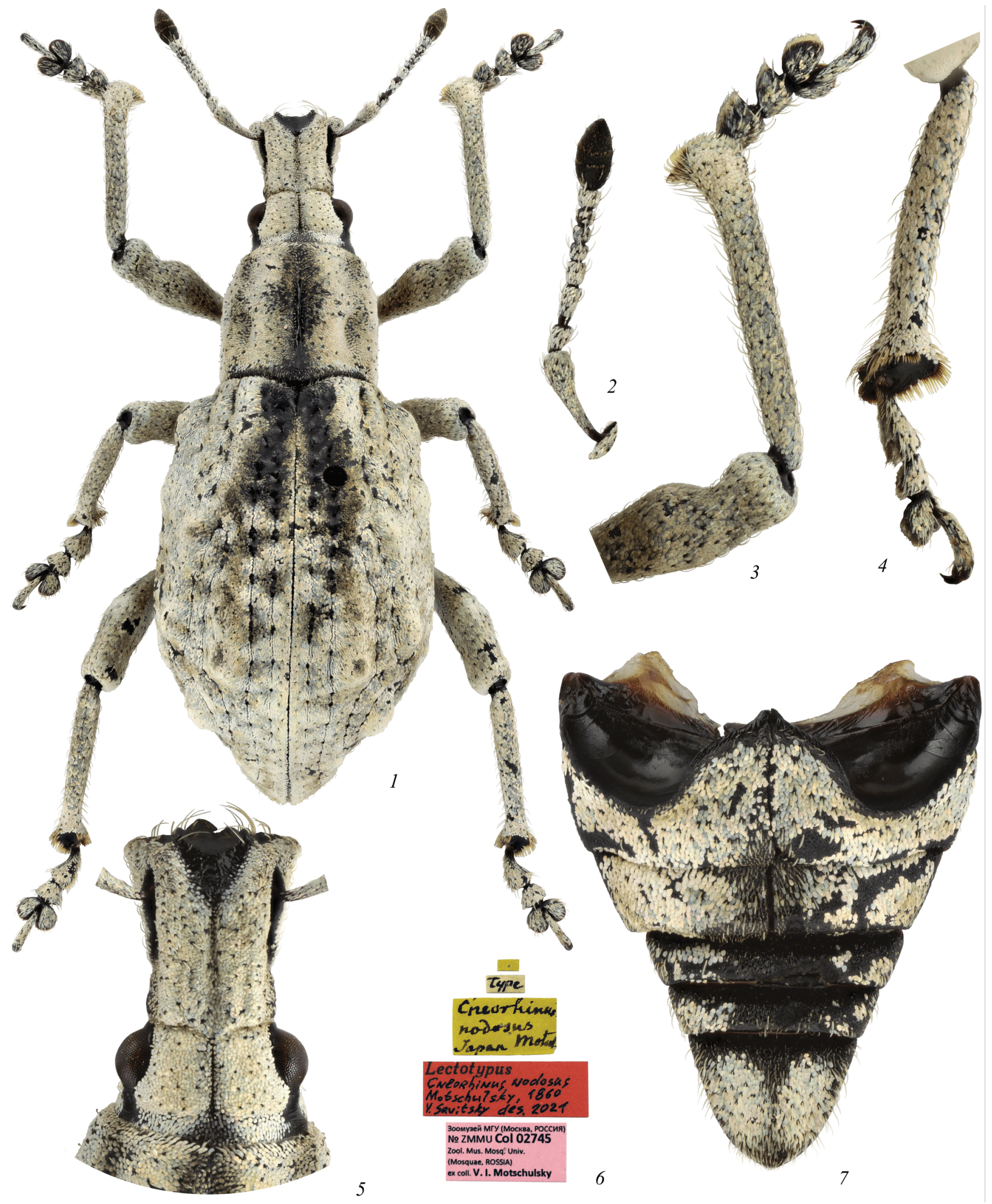

Fig. 5. Cneorhinus nodosus Motschulsky, lectotype: (1) habitus, (2) left antenna, (3) fore right leg, (4) hind right leg, (5) head in dorsal view, (6) labels, (7) venter. 


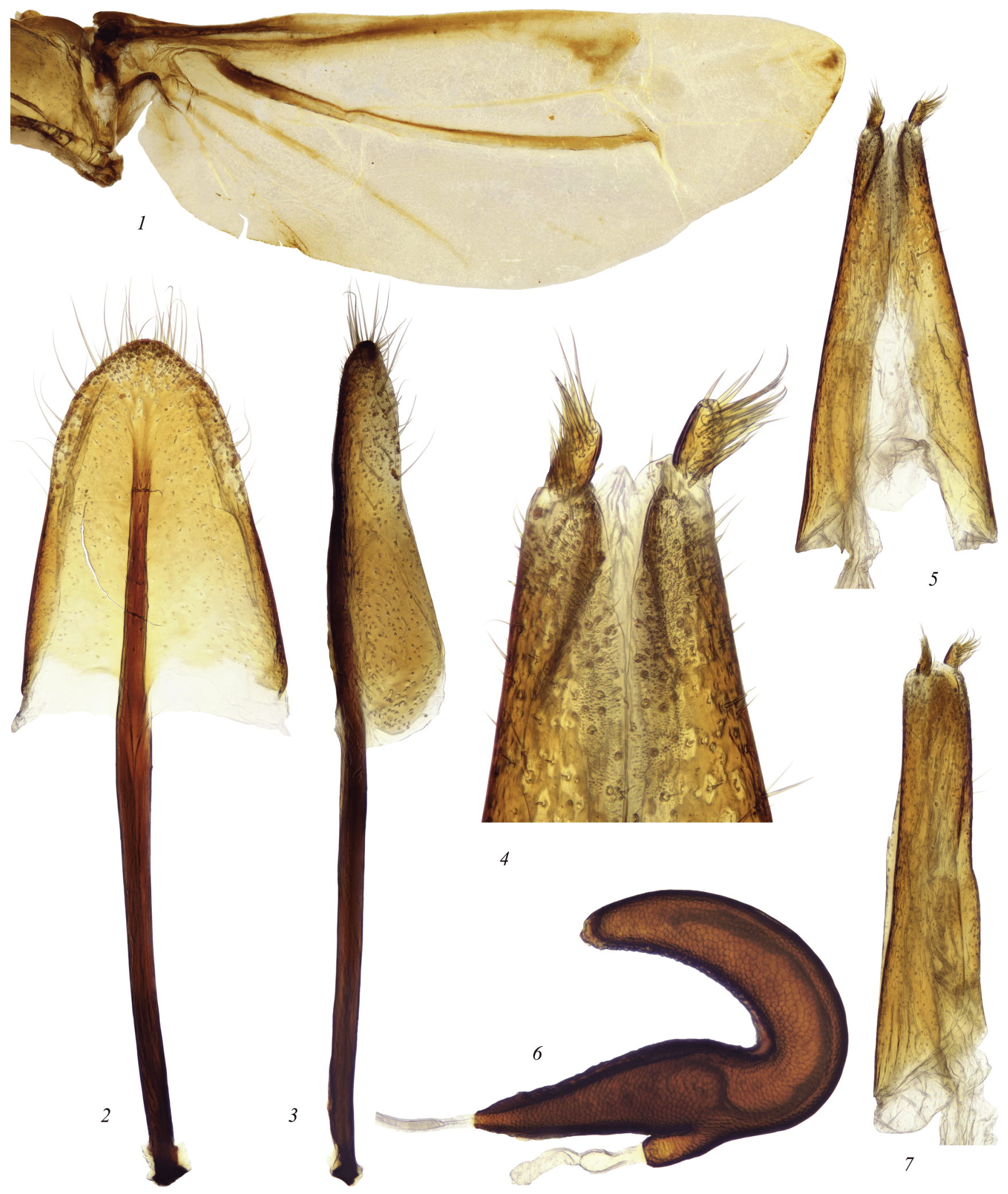

Fig. 6. Cneorhinus nodosus Motschulsky, lectotype: (1) right wing in dorsal view, (2) spiculum ventrale in ventral view, (3) spiculum ventrale in lateral view, (4) apex of coxites in dorsal view, (5) coxites in dorsal view, (6) spermatheca, (7) coxites in lateral view. 
ered Cneorhinus nodosus a synonym of Dermatoxenus caesicollis.

Below I include the data supplementing the previously published description of the female of Dermatoxenus caesicollis (Morimoto et al., 2015).

Elytra not merged along suture. Wings reduced, with well-developed cubital vein and shortened apical membrane, 2.7 times as long as wide; elytra 1.2 times as long as wings. Corbels of hind tibiae wide, almost oval, as densely covered with scales as most of body surface; integument completely obscured with scales. Articulatory areas on hind tibiae glabrous.

Abdomen approximately 1.2 times as long as wide. Intercoxal protrusion of ventrite I 1.2-1.3 times as wide as coxal cavities. Apex of anal ventrite dorsally with 2 indistinct protrusions.

Lamella of spiculum ventrale noticeably longer than wide, with quite narrowly rounded apical margin and excurved lateral margins. Manubrium approximately 1.5 times as long as lamella, narrow; caput quite small. Tergites VII and VIII weakly transverse, of similar shape, covered only with simple setae; apical margin of tergite VII weakly emarginate, that of tergite VIII broadly blunted.

Coxites long, moderately sclerotized; their dorsal surface distally along inner margin with areas of very fine and dense tubercles surrounding much larger, circular tubercles at bases of setae. Styli apical, elongate, dorsally densely covered with setae. Female reproductive tract without sclerotized elements. Vagina longer than coxites, approximately twice as long as bursa copulatrix. Collum of spermatheca much larger than ramus, gradually narrowing toward apex; cornu uniformly curved. Entire surface of spermatheca with reticulate microsculpture. Spermathecal duct not sclerotized, thickened in distal portion.

Crop unarmed. Lobes of proventriculus distally with merged plates.

Distribution. East and South China, Taiwan, Japan (Mahendiran and Ramamurthy, 2012; Morimoto et al., 2015). In the opinion of $\mathrm{K}$. Morimoto and co-authors (Morimoto et al., 2015), the records of D. caesicollis from Korea (Alonso-Zarazaga et al., 2017, etc.) actually refer to some closely related undescribed species.

\author{
Notes on Wing Reduction in Weevils \\ of the Tribes Cneorhinini and Blosyrini
}

According to K. Morimoto and co-authors (Morimoto et al., 2015), the hind wings in species of the tribe Cneorhinini are more or less reduced and non-functional. This is quite true of Dermatoxenus caesicollis as well as of species of the genus Catapionus and Eustal$i d a$ sp. from Nepal, studied by me. In the latter species, similar to D. caesicollis, the scutellum is concealed in dorsal view; the elytra are not merged along the suture; the wings are 4.5 times as long as wide and have a well-developed cubital vein and a shortened apical membrane; the elytra are 1.15 times as long as the wings.

However, many species of the tribe Cneorhinini, which used to be placed in a separate tribe Dermatodini, possess fully developed wings with complete venation and a long apical membrane. For instance, in two Dermatoxenus species from Vietnam the wings are approximately 2.8 times as long as wide and 1.55 and 1.40 times as long as the elytra, respectively. In the species with relatively longer wings the scutellum is concealed in dorsal view, while the other species has a well-developed scutellum, slightly raised above the level of the sutural interstriae. The wings are also fully developed in Dermatodes albarius Faust, 1892, D. dajacus Heller, 1915, and four species of the genus Stigmatrachelus studied by me. It remains unknown if their wings are functional, since there are no published data on the flight capability of these weevils.

Marshall (1916) noted that the tribe Blosyrini comprised wingless species, whereas K. Morimoto and coauthors (Morimoto et al., 2015) stated that weevils of this tribe had rudimentary wings. However, wings are well developed at least in specimens of Blosyrus asellus (Olivier, 1807) from Vietnam. These weevils seem to be able to fly because they were collected in considerable numbers in light traps in sweet potato plantations on the Hawaiian Islands (McQuate et al., 2016). Blosyrus oniscus (Olivier, 1807) and B.? herthus (Herbst, 1797), similar to $B$. asellus, possess a well-developed scutellum and non-merged elytra; at the same time, they have strongly reduced, narrow, lobe-like wings with no traces of venation and only $1 / 2-1 / 3$ times as long as the elytra.

Thus, in the process of wing reduction in weevils of the subfamily Entiminae the visible part of the scutellum may totally disappear (Dermatoxenus caesicollis) 
or be preserved (Blosyrus oniscus). In both cases, the elytra do not always merge along the suture. Of special interest are cases when the visible part of the scutellum disappears completely before the beginning of wing reduction, as in some Dermatoxenus species. On the whole, the degree of wing development in Entiminae weevils should be assessed by examination of the wings themselves and not merely inferred from external features consistent with aptery, such as disappearance of the scutellum and humeri, merging of the elytra along the suture, reduction of the metanotum length, etc. (for details, see Zherikhin and Egorov, 1990).

\section{Tribe Tanymecini}

Genus Scepticus Roelofs, 1873

Scepticus carinulatus (Motschulsky, 1866), comb. n.

Dermatodes carinulatus Motschulsky, 1866 : 179.

In all the characters, $D$. carinulatus most closely resembles Scepticus insularis Roelofs, 1873 and S. konoi Naramura et Morimoto, 2015; correspondingly, D. carinulatus is transferred here to the genus Scepticus.

One syntype was studied: Dermatodes carinulatus Motschulsky, 1866 (ZMMU), a female which is designated here as the lectotype. The specimen has the following labels (Fig. 7, 6): (1) a tiny yellow square; (2) "Dermatodes carinulatus Motsch Japonia" in V.I. Motschulsky's handwriting on yellow paper; (3) "Lectotypus Dermatodes carinulatus Motschulsky, 1866 V. Savitsky des. 2021" in V.Yu. Savitsky's handwriting on red paper; (4) "Zoological Museum of MSU (Moscow, RUSSIA) [in Russian] № ZMMU Col 02757 Zool. Mus. Mosq. Univ. (Mosquae, ROSSIA) ex coll. V.I. Motschulsky" printed on pink paper.

The lectotype (Fig. 7; Fig. 8, 1-4, 6, 7, 10; Fig. 9, 1) is remounted onto a rectangular cardboard plate, with the abdominal ventrites glued separately in the back left corner. The cleaned genitalia, terminalia, and proventriculus are kept in a microvial with glycerol. Only the first tarsomere is preserved in the fore right and hind left tarsi; the elytra are separated in the apical half; the lateral body pubescence is partly worn out. The body is $7.7 \mathrm{~mm}$ long and $3.5 \mathrm{~mm}$ wide.

Besides the lectotype of D. carinulatus, the ZMMU collection includes the following material of S. carinulatus.
Material. Russia. Sakhalin Province, Kunashir Island: mouth of Severyanka River, $44^{\circ} 20^{\prime} 23^{\prime \prime} \mathrm{N}, 146^{\circ} 00^{\prime} 12^{\prime \prime} \mathrm{E}$, 1-3.VII.2008 (I.V. Melnik), 1 \&; env. of Yuzhno-Kurilsk, 11.VIII.1992 (A.V. Sokolov), 1 P; WSW of YuzhnoKurilsk, env. of Tretyakovo, forest in valley of Valen-

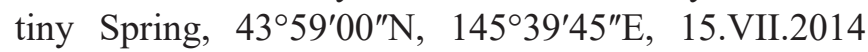
(A.S. Prosvirov), 1 q; Goryachii Plyazh, 10-30.VIII.1991 (M.V. Shestopalov), 1 क; Mendeleevo, 15.VII.1985 (V.V. Belov), 1 +. Japan. Hokkaido Island, Sapporo, 30.VII.1979 (A.G. Ponomarenko), 1 \%.

The specimens of Scepticus carinulatus studied by me generally correspond to the published descriptions of S. insularis and S. konoi (Morimoto et al., 2015). Some additional characteristics of the female of $S$. carinulatus are given below.

Pronotum at base 1.05-1.15 times as wide as at apex (1.15 times as wide in lectotype of Dermatodes carinulatus). Elytra in middle third almost parallel-sided; odd interstriae convex, 9th and 10th interstriae distinctly depressed at the level of hind coxae.

Abdomen 1.15-1.22 times as long as wide. Intercoxal protrusion of ventrite I 1.75-2.0 times as wide as coxal cavities. Anal ventrite weakly transversely convex in middle part, its apex dorsally without protrusions.

Lamella of spiculum ventrale noticeably longer than wide, with rounded apical margin and widely excurved lateral margins. Manubrium 1.65-2.30 times as long as lamella, narrow; caput quite small. Tergites VII and VIII of strongly different shapes (Fig. 8, 6, 7); tergite VII noticeably wider than long, with broadly blunted or weakly emarginate apical margin; tergite VIII barely wider than long, with broadly incurved lateral margins and relatively narrowly rounded apical margin. Lamella of spiculum ventrale and tergite VIII covered with simple setae; tergite VII covered with simple and pinnate setae (Fig. 8, 10).

Coxites long, quite strongly sclerotized, distally with S-curved and strongly sclerotized inner dorsal margin. Styli apical, large, elongate, dorsoventrally flattened, strongly sclerotized, glabrous along nearly their entire length, only near base with dorsal tuft of long setae. Female reproductive tract without sclerotized elements; vagina about as long as coxites, bursa copulatrix very small. Spermatheca usually strongly sclerotized, ramus noticeably larger than collum, cornu almost straight in distal part, with beak-shaped bend only at its very 
apex (Fig. 9, 1-6). Collum and basal part of ramus with reticulate microsculpture, more distinct in less strongly sclerotized spermathecae; surface of cornu smooth. Spermathecal duct sclerotized along its entire length.

Crop covered with moderately dense narrow spicules in distal half (Fig. 8,8) and with very fine denticles in proximal half (Fig. 8, 9).

Lobes of proventriculus distally with merged plates; each lobe with club-shaped apical structure bearing denticles directed inwards and backwards (Fig. 8, 5). Sclerotized parts of spicules directed into proventriculus lumen flattened, gradually narrowing toward apex.

Distribution. Russia (Kunashir Island), Japan (Hokkaido Island). Type locality of Dermatodes carinulatus: Hokkaido Island, environs of Hakodate.

Comparative notes. Scepticus carinulatus resembles $S$. konoi in the elytra being almost parallel-sided in their middle third and in the convex odd interstriae. On the contrary, the distinct depression of the 9th and 10th interstriae at the level of the hind coxae corresponds to the description of $S$. insularis (Morimoto et al., 2015). The ratio of the pronotum width at its base to that at its apex is 1.05 in $S$. konoi and 1.15 in S. insularis (Morimoto et al., 2015), whereas in S. carinulatus it is $1.05-$ 1.15 .

Scepticus insularis and S. konoi are widely distributed in Japan, but only S. konoi was recorded for Hokkaido Island (Morimoto et al., 2015). In my opinion, of all the characters proposed by the Japanese authors for differentiating these species, only the structural features of the elytra and aggonoporium ("flagellum" in the cited publication) may be reliable. The two species can hardly be differentiated by the ratio of the basal and apical pronotal widths, judging by the level of variation of this character determined by the measurements of only seven specimens of $S$. carinulatus. The distinct depression of the 9th and 10th interstriae at the level of the hind coxae most probably constitutes a secondary sexual character in this group. In particular, this depression is present in all the females of several species of the genus Scepticus and also a very closely related species Meotiorhynchus querendus Sharp, 1896, studied by me. At the same time, in males of $S$. tigrinus (Roelofs, 1873), S. noxius (Faust, 1886), and M. querendus the 9th and 10th interstriae are flat or weakly depressed at the level of the hind coxae.
Thus, S. konoi is quite possibly a synonym of S. carinulatus (Motschulsky, 1866); however, for the time being I refrain from establishing the new synonymy since I do not have sufficient material of the genus Scepticus from Japan and I have not examined any males of $S$. carinulatus.

Genus Amystax Roelofs, 1873

\section{Amystax fasciatus Roelofs, 1873}

Distribution. Japan: Kyushu Island, Goto Islands, and Danjo Islands (Morimoto et al., 2015).

The specimen of Scepticus carinulatus collected by M.V. Shestopalov on Kunashir Island has a label "Amystax fasciatus Roel. V. Zherichin det. 91." Before the finding of this specimen, the genus Amystax Roelofs, 1873 was not included in the review of weevils of the Far East of the USSR (Zherikhin and Egorov, 1990). Thus, the records of Amystax fasciatus for Kunashir Island (Egorov et al., 1996; Ren et al., 2013b; AlonsoZarazaga et al., 2017) were based on misidentification and in fact referred to $S$. carinulatus. It should also be noted that, according to K. Morimoto and co-authors (Morimoto et al., 2015), species of the genus Amystax are distributed only in Japan, but they are unknown on Hokkaido Island and in the northern half of Honshu Island.

\section{Morphological Notes on Weevils of the Tribe Tanymecini}

My examination of Meotiorhynchus querendus, Scepticus tigrinus, $S$. noxius (Kyrgyzstan, Trans-Alay Range), and Scepticus sp. (India, Himachal Pradesh, Pir Panjal Range) has revealed generally the same structure of the female terminalia and genitalia, and also the crop and proventriculus, as that in S. carinulatus. In particular, tergite VII in females of all these species is covered with simple and pinnate setae (as in Fig. 8, 10, 11); the coxites distally have an S-curved and strongly sclerotized inner dorsal margin; the styli are apical, large, scoopshaped, and glabrous, with only a basal tuft of setae; the spermatheca has a characteristic shape with the cornu almost straight distally and beak-shaped at the apex (Fig. 9, 7-15) and the duct sclerotized along its entire length; the crop is covered with fine denticles proximally and with narrow spicules distally (as in Fig. 8, 8, 9); the proventricular lobes bear club-shaped apical structures with rather large denticles (as in Fig. 8, 5). 


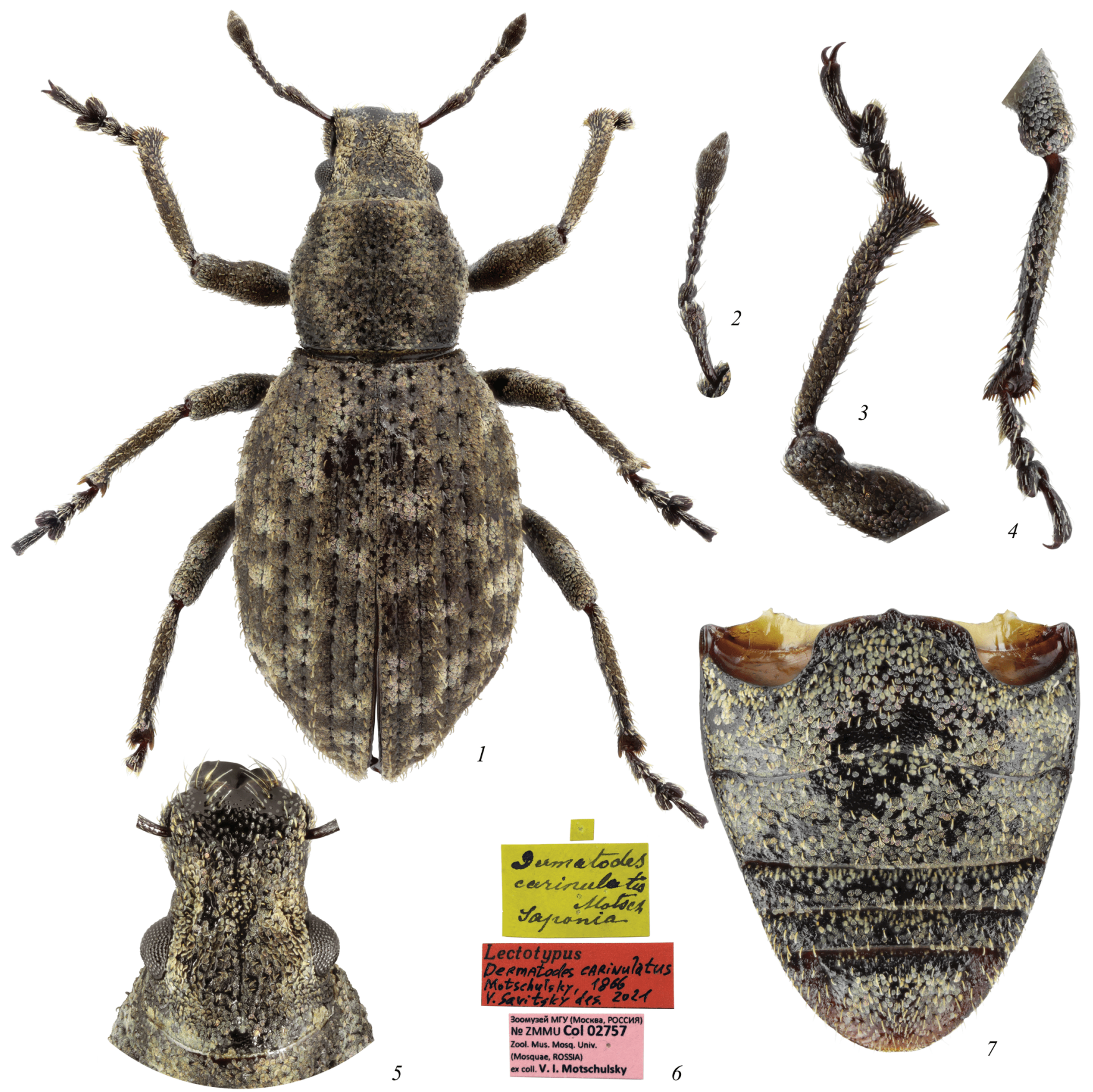

Fig. 7. Dermatodes carinulatus Motschulsky, lectotype: (1) habitus, (2) left antenna, (3) fore left leg, (4) hind right leg, (5) head in dorsal view, (6) labels, (7) venter.

To estimate the diagnostic significance of these characters, I have additionally studied species from 15 genera representing all the subtribes of Tanymecini.

Tergite VII in females of most of the studied species is covered only with simple setae. In females of Chloro- phanus vittatus Schoenherr, 1832 and Phacephorus nebulosus Fåhraeus, 1840 this tergite is covered with simple and pinnate setae, as in Scepticus and Meotiorhynchus. In females of Diglossotrox mannerheimi Lacordaire, 1863 and species of the genus Xylinophorus Faust, 1885 tergite VII bears not only simple setae but 

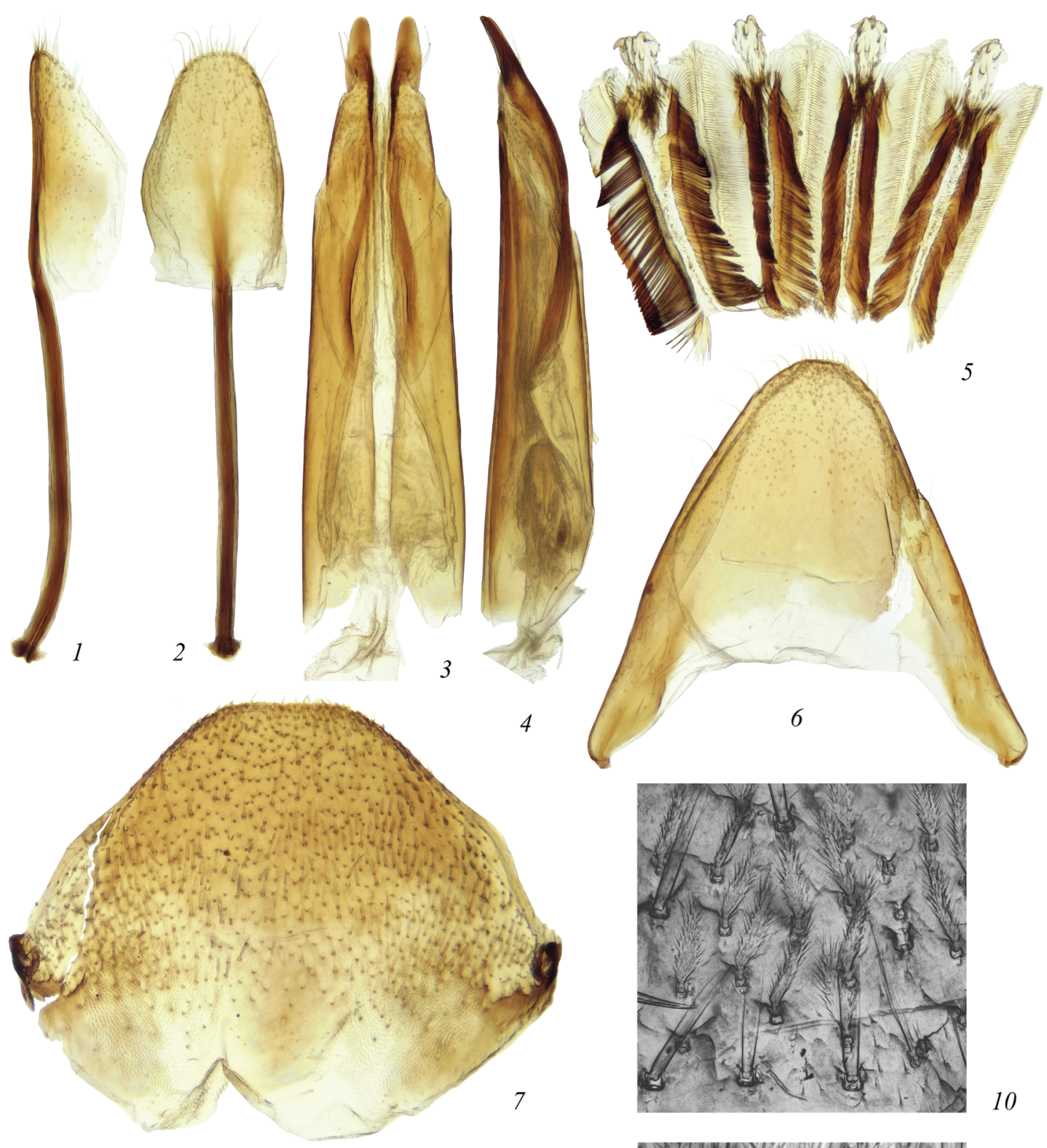

10

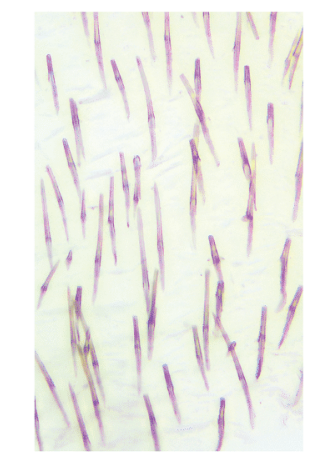

8
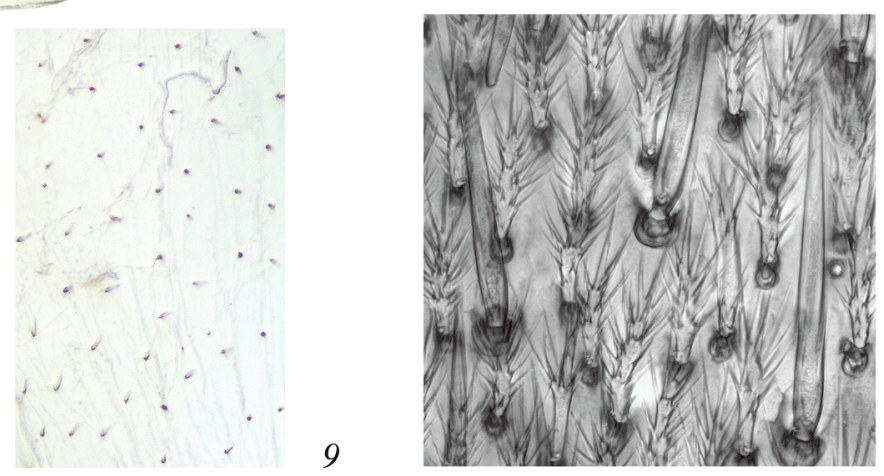

11

Fig. 8. Spiculum ventrale in lateral (1) and ventral view (2), coxites in dorsal (3) and lateral view (4), lobes of proventriculus in inner view (5), tergite VIII of female in dorsal view (6), tergite VII of female in dorsal view (7), armature of distal (8) and proximal (9) part of crop, and fragment of median part of distal half of tergite VII of female in dorsal view $(10,11):(1-4,6,7,10)$ Dermatodes carinulatus Motschulsky, lectotype, $(5,8,9)$ Scepticus carinulatus (Motsch.): (5) Kunashir Island, Tretyakovo, (8, 9) Hokkaido Island, Sapporo, (11) Meotiorhynchus querendus Sharp (Kunashir Island, Andreevskii base). 
2272

2222

222

227 
also setae split into $2-8$ parts; in $X$. scobinatus Kolenati, 1858 such setae sometimes look almost like pinnate ones. In females of Protenomus saisanensis Schoenherr, 1826 tergite VII bears rather sparse simple setae and much more numerous shorter, fusiform setae.

Species of the tribe Tanymecini vary strongly in the shape and sclerotization of the coxites; yet the exact sclerotization pattern of the inner coxite margins typical of Scepticus and Meotiorhynchus has not been found in any other species of this tribe.

Very large apical styli without apical setae, almost merged with the coxites, similar to those of Scepticus and Meotiorhynchus, can also be found in Dereodus sp. from Nepal and in species of the genus Chlorophanus Sahlberg, 1823 (e.g., see Morimoto et al., 2015: pl. 93, F, J; 94, C, J, L). In the rest of the studied species the styli are small (very small in Protenomus saisanensis), much narrower than the distal portions of the coxites, and have apical setae. Phacephorus nebulosus, Megamecus (s. str.) variegatus (Gebler, 1829), Piazomias semenovi Suvorov, 1915, Meteutinopus mongolicus Faust, 1881, and species of the genera Xylinophorus and Hyperomias Marshall, 1916 have subapical styli, whereas Megamecus (Acercomecus) argentatus (Gyllenhal, 1840), Diglossotrox mannerheimi, Protenomus saisanensis, Geotragus sp., Leptomias sp., and Aspidiotes cottyi Lucas, 1858 have apical styli.

Some authors erroneously noted that species of the genus Megamecus Reitter, 1903 possessed ovipositors (= coxites) with strongly sclerotized hook-shaped appendages (Arnoldi et al., 1965; Baitenov, 1974). In fact, the paired appendages are apical processes of the strongly sclerotized lamella of the spiculum ventrale (e.g., see Supare et al., 1990: figs. 249-289). The same structure of the lamella of the spiculum ventrale is observed in species of the genus Esamus Chevrolat, 1880, Diglossotrox mannerheimi, and Protenomus saisanensis.

Most of the studied species of the tribe Tanymecini differ well from Scepticus and Meotiorhynchus in the spermatheca morphology (compare the drawings in Supare et al., 1990; Poorani and Ramamurthy, 1997; Ren et al., 2007, 2013a; Ramamurthy and Ayri, 2010; Morimoto et al., 2015; Kumar et al., 2016; Song et al., 2017). Only some species of the genera Geotragus Schoenherr, 1845 and Hyperomias have spermathecae of nearly the same shape as those in Scepticus and Meotiorhynchus.
The spermathecal duct is more or less sclerotized along its entire length or part of it in most species of the tribe Tanymecini. In the subtribe Piazomiina the sclerotized duct is coiled (e.g., see Song et al., 2017: figs. 19, $22,40,41)$ or sinuous, similar to that of Scepticus sp. and $S$. noxius. Such species as Phacephorus nebulosus, Megamecus variegatus, Protenomus saisanensis, Diglossotrox mannerheimi, and Aspidiotes cottyi have membranous or barely sclerotized spermathecal ducts. The spermathecal duct of $P h$. nebulosus, $M$. variegatus, $P$. saisanensis, and D. mannerheimi is considerably shorter than that of other species and thickened distally; the latter feature is also typical of species of the genus Chlorophanus.

All the additionally studied species of the tribe Tanymecini differ well from Scepticus and Meotiorhynchus in the crop morphology. In most of them the crop is covered with narrow spicules along its entire length, while in Chlorophanus vittatus and Lepropus sp. from Vietnam the spicules are present only in the proximal part.

The proventricular lobes in all the studied species of the tribe Tanymecini bear apical structures with denticles directed backwards. In most species these structures are triangular or trapeziform pads of varying width, covered with fine imbricated denticles (e.g., see Song et al., 2017: fig. 17). Only Xylinophorus sp. from Iran and ? Geotragus sp. from Vietnam have club-shaped structures with large denticles (as in Fig. 8, 5), similar to those in Scepticus and Meotiorhynchus.

Thus, most of the specific features of the crop, proventriculus, and the female terminalia and genitalia typical of Scepticus and Meotiorhynchus can also be found in other genera within the tribe Tanymecini. However, the complex of these features very reliably characterizes Scepticus and Meotiorhynchus and differentiates them from other genera of this tribe. Besides, Meotiorhynchus querendus and all the Scepticus species have a specific structure of the antenna, with the 7th funicle segment strongly enlarged and incorporated into the club (as in Fig. 7,2), and also a similar morphology of the aedeagus, including the aggonoporium. In addition, it should be noted that the elytra of both $M$. querendus and the Scepticus species examined by me are usually merged along the suture. The wings of $M$. querendus are strongly reduced, lobe-shaped, with no trace of veins, approximately 2.25 times as long as wide and 0.28 times as long as the elytra; the wings of Scepticus noxius are totally 
absent, and the degree of wing development in other Scepticus species is unknown.

On the whole, my new data confirm the opinion of K. Morimoto and co-authors (Morimoto et al., 2015) that the genera Meotiorhynchus and Scepticus are taxonomically close, and also demonstrate that Meotiorhynchus querendus and species of the genus Scepticus from both the western and the eastern parts of its disjunct range form a single monophyletic group, distinct from the other genera of the subtribe Tanymecina.

\section{ACKNOWLEDGMENTS}

I am sincerely grateful to N.V. Belyaeva, K.V. Makarov, A.S. Prosvirov, A.A. Polilov, D.N. Fedorenko, and E.O. Shcherbakov (Moscow) for the material provided for study, and also to B.A. Korotyaev (St. Petersburg) for valuable comments on the manuscript.

\section{FUNDING}

This work was supported by the State research assignment 121032300105-0 at Moscow State University.

\section{COMPLIANCE WITH ETHICAL STANDARDS}

All the applicable international, national, and/or institutional guidelines for the care and use of animals were followed. All the procedures performed in studies involving animals were in accordance with the ethical standards of the institution or practice at which the studies were conducted.

\section{OPEN ACCESS}

This article is licensed under a Creative Commons Attribution 4.0 International License, which permits use, sharing, adaptation, distribution and reproduction in any medium or format, as long as you give appropriate credit to the original author(s) and the source, provide a link to the Creative Commons license, and indicate if changes were made. The images or other third party material in this article are included in the article's Creative Commons license, unless indicated otherwise in a credit line to the material. If material is not included in the article's Creative Commons license and your intended use is not permitted by statutory regulation or exceeds the permitted use, you will need to obtain permission directly from the copyright holder. To view a copy of this license, visit http://creativecommons.org/licenses/by/4.0/.

\section{REFERENCES}

Alonso-Zarazaga, M.A. et al., Cooperative Catalogue of Palaearctic Coleoptera Curculionoidea. Monografías electrónicas SEA 8, Zaragoza: Sociedad Entomológica Aragonesa, 2017. http://sea-entomologia.org/monoelec.html

Arnoldi, L.V., Zaslavsky, V.A., and Ter-Minassian, M.E., 82. Family Curculionidae, Weevils, in Opredelitel' nasekomykh evropeiskoi chasti SSSR (Key to Insects of the European Part of the USSR), Vol. 2: Zhestkokrylye i veerokrylye (Coleoptera and Strepsiptera), Guryeva, E.L. and Kryzhanovsky, O.L., Eds., Moscow: Nauka, 1965, p. 485.

Baitenov, M.S., Zhuki-dolgonosiki (Coleoptera: Attelabidae, Curculionidae) Srednei Azii i Kazakhstana (Weevils (Coleoptera: Attelabidae, Curculionidae) of Central Asia and Kazakhstan), Alma-Ata: Nauka, 1974.

Davidian, G.E. and Savitsky, V.Yu., Review of the weevil subgenera Namertanus Reitter and Troglonamertanus subgen. n., genus Otiorhynchus Germar (Coleoptera: Curculionidae), from the Caucasus, Tr. Russ. Entomol. O-va, 2006, vol. 77, p. 48.

Davidian, G.E. and Savitsky, V.Yu., New data on the taxonomy and morphology of weevils of the genus Plinthus (Coleoptera, Curculionidae), Zool. Zh., 2017, vol. 96, no. 7, p. 784 .

Egorov, A.B., Zherikhin, V.V., and Korotyaev, B.A., $112 b$. Family Curculionidae, Weevils, in Opredelitel' nasekomykh Dal'nego Vostoka Rossii (Key to Insects of the Russian Far East), Vol. 3: Zhestkokrylye, ili zhuki (Coleoptera, Beetles), Part 3, Lelej, A.S., Ed., Vladivostok: Dalnauka, 1996, p. 431. Emden, M. van and Emden, F.I. van, Curculionidae: Brachyderinae III, in Coleopterorum catalogus auspiciis et auxilio W. Junk. Pars 164, Schenkling, S., Ed., Berlin: W. Junk, 1939, p. 197.

Kania, J. and Dąbrowska, A., Revision of the genus Antinia Pascoe, 1871 (Coleoptera: Curculionidae: Brachyderinae), Genus, 1995, vol. 6, no. 3, p. 493.

Kania, J. and Piwnik, A., Notes on the genera Antinia Pascoe, 1871 and Dermatodina Faust, 1895 with description of D. boroveci sp. nov. from Thailand (Coleoptera: Curculionidae: Entiminae), Zootaxa, 2017, vol. 4232, no. 3, p. 322. https://doi.org/10.11646/zootaxa.4232.3.2

Kania, J. and Stojczew, A., Antinia holynskiorum sp. nov. from Vietnam (Coleoptera: Curculionidae: Entiminae: Dermatodini), Ann. Zool., 2001, vol. 51, no. 1, p. 89.

Kumar, D., Mahendiran, G., Ayri, S., and Ramamurthy, V.V., Review of the genus Geotragus Schoenherr, 1845 (Coleoptera: Curculionidae), with description of a new species from 
the Indian subcontinent, Pan-Pac. Entomol., 2016, vol. 92, no. 3 , p. 133 .

Mahendiran, G. and Ramamurthy, V.V., Redescription of two species of genus Dermatoxenus Marshall (Entiminae: Curculionidae: Coleoptera) from India, Bioscan, 2012, vol. 7, no. 2, p. 241.

Marshall, G.A.K., Coleoptera. Rhynchophora: - Curculionidae, in The Fauna of British India, Including Ceylon and Burma, London: Taylor and Francis, 1916.

McQuate, G.T., Sylva, C.D., and Kumashiro, B.R., First field collection of the rough sweetpotato weevil, Blosyrus asellus (Olivier) (Coleoptera: Curculionidae), on Hawaii Island, with notes on detection methods, Proc. Hawaiian Entomol. Soc., 2016, vol. 48, p. 1.

Morimoto, K., Nakamura, T., and Kannô, K., Curculionidae: Entiminae (Part 2) (Coleoptera), in The Insects of Japan. Vol. 4, Fukuoka: Touka Shobo, 2015.

Motschulsky, V.I., Insectes du Japon, Etud. Entomol., 1860, vol. 9, p. 4.

Motschulsky, V.I., Catalogue des insectes reçus du Japon, Bull. Soc. Imp. Natur. Moscou, 1866, vol. 39, no. 1, p. 163.

Motschulsky, V.I., Genres et espèces d'insectes, publiès dans différents ouvrages par Victor Motschoulsky, Horae Soc. Entomol. Ross., 1870, vol. 6, Suppl., p. 1.

Poorani, J. and Ramamurthy, V.V., Weevils of the genus Lepropus Schoenherr from the Oriental Region (Coleoptera: Curculionidae: Entiminae), Orient. Ins., 1997, vol. 31, p. 1.

Ramamurthy, V.V. and Ayri, S., Revision of the genus Indomias Marshall (Coleoptera, Curculionidae, Entiminae, Tanymecini) from India, Zootaxa, 2010, vol. 2357, p. 1.

Ren, L., Alonso-Zarazaga, M.A., and Zhang, R., Review of the Chinese Hyperomias Marshall (Coleoptera: Curculionidae: Entiminae) with description of a new species, Zootaxa, 2007, vol. 1562 , p. 1.

Ren, L., Alonso-Zarazaga, M.A., and Zhang, R., Revision of the Chinese Geotragus Schoenherr with description of three new species (Coleoptera: Curculionidae: Entiminae), Zootaxa, 2013a, vol. 3619, no. 2, p. 161.

Ren, L., Sánchez-Ruiz, M., and Alonso-Zarazaga, M.A., Tribe Tanymecini Lacordaire, 1863, in Catalogue of Palaearctic Coleoptera. Curculionoidea II. Vol. 8, Löbl, I. and Smetana, A., Eds., Leiden: Brill, 2013b, p. 86, 392.
Savitsky, V.Yu., Little-known weevil taxa (Coleoptera, Curculionidae) described by V.I. Motschulsky from the Caucasus, Entomol. Obozr., 2018, vol. 97, no. 1, p. 102.

Savitsky, V.Yu., On the little-known weevil taxa (Coleoptera, Curculionidae) described by V.I. Motschulsky from Japan and the taxonomic position of the subgenus Nipponoblosyrus Korotyaev, Entomol. Obozr., 2020, vol. 99, no. 2, p. 435. https://doi.org/10.31857/S0367144520020185

Savitsky, V.Yu., A new species of the weevil genus Dermatodina Faust (Coleoptera, Curculionidae) from Vietnam, Entomol. Obozr., 2021, vol. 100, no. 1, p. 181.

https://doi.org/10.31857/S0367144521010111

Sharp, D., The rhynchophorous Coleoptera of Japan. Part IV. Otiorhynchidae and Sitonides, and a genus of doubtful position from the Kurile Islands, Trans. Entomol. Soc. London, 1896, vol. 1896, no. 1, p. 81.

Song, Z., Ren, L., Zhang, R., and Zhou, C., Review of the species of Leptomias Faust from Sichuan, China (Coleoptera, Curculionidae, Entiminae), ZooKeys, 2017, vol. 678, p. 97. https://doi.org/10.3897/zookeys.678.12543

Supare, N.R., Ghai, S., and Ramamurthy, V.V., A revision of Tanymecus from India and adjacent countries (Coleoptera: Curculionidae), Orient. Ins., 1990, vol. 24, p. 1.

Thompson, R.T., Observations on the morphology and classification of weevils (Coleoptera, Curculionoidea) with a key to major groups, J. Nat. Hist., 1992, vol. 26, p. 835.

Tournier, H., Etude des espèces européennes et circumeuropéennes du genre Cneorhinus Schoenh. de la tribu des brachydérides, curculionides adélognathes cyclophthalmes, Ann. Soc. Entomol. Belg., 1876, vol. 19, no. 2, p. 125.

Yoshihara, K., Coleoptera, Curculionidae, Baridinae, in The Insects of Japan. Vol. 6, Fukuoka: Touka Shobo, 2016.

Zherikhin, V.V. and Egorov, A.B., Zhuki-dolgonosiki (Coleoptera, Curculionidae) Dal'nego Vostoka SSSR (obzor podsemeistv s opisaniem novykh taksonov) (Weevils (Coleoptera, Curculionidae) of the Far East of the USSR: Review of Subfamilies with Descriptions of New Taxa), Vladivostok, 1990. 